2016

\title{
Corruption at the Intersection of Business and Government: The OECD Convention, Supply- Side Corruption and Canada's Anti-Corruption Efforts to Date
}

Milos Barutciski

Sabrina A. Bandali

Follow this and additional works at: http:// digitalcommons.osgoode.yorku.ca/olsrps

Part of the International Law Commons

\section{Recommended Citation}

Barutciski, Milos and Bandali, Sabrina A., "Corruption at the Intersection of Business and Government: The OECD Convention, Supply-Side Corruption and Canada's Anti-Corruption Efforts to Date" (2016). Osgoode Legal Studies Research Paper Series. 134.

http://digitalcommons.osgoode.yorku.ca/olsrps/134 
Osgoode Legal Studies Research Paper No. 15

Vol. 12/ Issue. 3/ (2016)

\title{
Corruption at the Intersection of Business and Government: The OECD Convention, Supply-Side Corruption and Canada's Anti- Corruption Efforts to Date
}

Osgoode Hall Law Journal, Vol. 53(1), Forthcoming.

\author{
Milos Barutciski \\ Sabrina A. Bandali
}

\begin{abstract}
:
Over the last twenty years, international and regional conventions have been concluded to combat the corruption of public officials. Part I of the paper explains the genesis of international anti-corruption law and its focus on the "supply-side" of bribery transactions, drawing on the negotiating history and the experience of practitioners involved in the development of international anti-corruption law. Parts II and III provide examine Canada's implementation of its international obligations and its enforcement record to date. Part IV of the paper concludes with an analysis of the challenges faced by Canadian businesses and the limitations of the focus on supply-side of bribery transactions.
\end{abstract}

\section{Keywords:}

Supply-side corruption; anti-corruption compliance; foreign bribery; international anticorruption; OECD Convention; CFPOA

\section{Author(s):}

Milos Barutciski

Sabrina A. Bandali

E: BarutciskiM@bennettjones.com

E: BandaliS@bennettjones.com 


\title{
Corruption at the Intersection of Business and Government: The OECD Convention, Supply-Side Corruption and Canada's Anti-Corruption Efforts To Date
}

\author{
Milos Barutciski and Sabrina A. Bandali, Bennett Jones LLP ${ }^{1}$
}

In 1997, Canada and 33 other Members of the Organization for Economic Co-operation and Development (OECD) signed the Convention on Combating Bribery in International Business Transactions (the OECD Convention). ${ }^{2}$ The signature and ratification of this convention marked an important milestone in a campaign against corruption that had been picking up momentum through the early 1990s.

The principal thrust of the campaign was to tackle supply-side corruption, that is, to counter official corruption by cutting off the supply of bribe payments. Although all countries prohibit bribery of their own officials, the United States (US) was the only country in the world that expressly prohibited the payment of bribes to foreign officials prior to the entry into force of the OECD Convention entry on February 15, 1999 as a result of the enactment of the Foreign Corrupt Practices Act (FCPA) ${ }^{3}$ in 1977.

Subsequent to the development of the international consensus on addressing the supply-side of bribery transactions, several trends have driven multinational enterprises to focus on anticorruption compliance. The increase in corporate focus on these issues has in turn encouraged the emergence of specialized anti-corruption compliance professionals, investigators, lawyers, and other advisors. While the focus on the supply-side has produced significant improvements in training, internal controls and corporate compliance generally, it has also created significant direct and indirect costs for companies, ${ }^{4}$ which can quickly become difficult to control or make proportional to the corruption risk at issue. In addition, even the most robust compliance regimes can be circumvented if the incentives are high enough, and circumventers devote sufficient effort. So long as the efforts to constrain supply-side corruption are not matched by equivalent efforts on the demand side, there will be inefficiencies and misallocation of resources in both compliance activities and in the broader international campaign against corruption.

This paper aims to explain the development and limits of the focus on supply side corruption from the perspective of a practitioner who participated in the genesis and implementation of the supply-side approach. Part I of this paper explains the origins of the international focus on the supply-side of bribery transactions, memorialized in the OECD Convention, based on process documents and the experience of practitioners involved in the development of this approach. Notwithstanding the broader scope of subsequent anti-corruption conventions, such as the United

\footnotetext{
${ }^{1}$ Presented at the Osgoode Hall Law Journal Symposium on November 6, 2014. Milos Barutciski is a partner and co-head of the International Trade and Investment Group at Bennett Jones LLP. Sabrina A. Bandali is an associate with the Group. The authors would like to thank Evan Kenyon, Student-at-Law, Bennett Jones LLP, for his research assistance in the preparation of this paper. The views and opinions expressed are the authors' own and do not reflect the view of the organizations that the author may represent.

${ }^{2}$ Convention on Combating Bribery of Foreign Public Officials in International Business Transactions, 17 December 1997, 37 ILM 1 [OECD Convention].

${ }^{3}$ Foreign Corrupt Practices Act of 1977, 15 USC $\S$ 78m, 78dd-1-78dd-3, 78ff (1977).

${ }^{4}$ Corporate anti-corruption compliance entails substantial direct and indirect costs at both the operational day-to-day level and in the transactional deal context (i.e., mergers and acquisitions, joint ventures, borrowing and financing, etc.). Direct costs include the administrative costs of maintaining compliance staff, training, monitoring and audit, third-party due diligence, counsel and forensic investigation fees and other costs related to the ongoing implementation of compliance procedures. There are also substantial indirect costs that come into play in the context of impacts on commercial negotiations, diversion and distraction of management resources and the costs of delay in implementing transactions resulting from due diligence and other compliance-related activities.
} 
Nations Convention against Corruption (UNCAC), ${ }^{5}$ combating supply-side corruption remains the dominant focus of Canada's implementation of its international anti-corruption obligations. Accordingly, Part II of the paper presents an overview of Canada's record to date in implementing those obligations, including both the adoption of the Corruption of Foreign Public Officials Act (CFPOA), ${ }^{6}$ legislative changes to CFPOA in 2013 and the evolution of Canadian law enforcement efforts. Part III presents some reflections on the limits of the OECD Convention's current approach, and suggestions for future directions.

\section{OVERVIEW OF THE INTERNATIONAL RULES}

\section{A. International Conventions Addressing Anti-Corruption}

Over the last twenty years, several international and regional conventions have been concluded to combat official corruption. These include the Inter-American Convention against Corruption in 1996, ${ }^{7}$ the OECD Convention in $1997,{ }^{8}$ the Council of Europe Criminal Law Convention on Corruption in 1999, ${ }^{9}$ the African Union Convention on Preventing and Combating Corruption in 2003, ${ }^{10}$ and the UNCAC, also in 2003. ${ }^{11}$ Of these, the instrument that has had the greatest impact on international business is the OECD Convention.

\section{B. Genesis of the Focus on Supply-Side Corruption (Bribe Payers)}

Before the OECD Convention, bribing a foreign public official was not only tolerated, but was legally permissible everywhere except in the US. In fact, in Canada and many other jurisdictions, the cost of paying a bribe was a deductible business expense for income tax purposes. ${ }^{12}$ This practice only changed in 1996 as a result of an OECD Recommendation calling for the elimination of tax deductibility for bribes, a precursor of the OECD Convention. ${ }^{13}$ (Indeed, the preferential tax treatment of bribes continued to be an issue after the OECD Convention's adoption. $)^{14}$

There are several reasons for the historical tolerance of foreign bribery. The first is the predominantly territorial basis of criminal law. ${ }^{15}$ When a company pays a bribe to foreign official in a host country, the actus reus of the bribery offence often occurs entirely in the host country, and outside of the territorial jurisdiction of the company's home country laws. Accordingly, absent rules conferring nationality-based or some other form of extraterritorial jurisdiction, the company's home country cannot assert adjudicative jurisdiction over the offence. Second, the principles of international comity and sovereign equality make it improper —or at the very least difficult-for one country to dictate norms of conduct for officials of another

\footnotetext{
${ }^{5}$ United Nations Convention against Corruption, 9 December 2003, 2349 UNTS 41 (entered into force 14 December 2005) [UNCAC].

${ }^{6}$ Corruption of Foreign Public Officials Act, SC 1998, c 34 [CFPOA].

${ }^{7}$ Inter-American Convention against Corruption, 29 March 1996, OASTS B-58.

${ }^{8}$ OECD Convention.

${ }^{9}$ Criminal Law Convention on Corruption, 27 January 1999, Eur TS No 173 (entered into force 1 July 2002).

${ }^{10}$ African Union Convention on Preventing and Combating Corruption, 11 July 2003, 43 ILM 5 (entered into force 5 August 2006).

${ }^{11}$ UNCAC.

${ }^{12}$ Section 67.5 of the Income Tax Act, RSC, 1985, c 1 (5th Supp) now prohibits deducting expenses incurred for the purpose of doing anything that would be an offence under section 3 of the CFPOA or the domestic bribery provisions of the Criminal Code.

${ }^{13}$ Recommendation of the Council on the Tax Deductibility of Bribes to Foreign Public Officials, 11 April 1996, 35 ILM 1311 (OECD).

${ }^{14}$ United States Department of State, Battling International Bribery: The First Annual Report on Enforcement and Monitoring of the OECD Convention on Combating Bribery of Foreign Public Officials in International Business Transactions (Washington, D.C.: Bureau of Economic and Business Affairs, 30 June 1999) at vi [United States Department of State, Battling International Bribery].

${ }^{15}$ Noted as a general principle by the Supreme Court of Canada in Libman v The Queen, [1985] 2 SCR 178 at para 11 [Libman].
} 
sovereign country in the foreign sovereign's territory. Third, both companies and governments have historically followed a pragmatic and relativistic approach to transactions and commercial operations in multiple jurisdictions: "when in Rome, do as the Romans do."

As the scope and volume of international business has expanded, all three of these rationales for tolerating foreign corruption have increasingly come under criticism. International and domestic laws, standards, and commercial norms have developed that depart from these three principles. Nonetheless, in the years leading up to the OECD Convention, the principles of territoriality, comity and sovereign equality, and pragmatic relativism made the emergence of an international consensus on anti-corruption far from inevitable.

\section{Genesis of the International Anti-Corruption Consensus}

The origins of the international consensus to tackle corruption through coordinated international efforts was the result of two parallel movements during the early 1990s. The first came from non-governmental organizations (NGOs), notably Transparency International (TI), who were motivated by the frustration of seeing billions of dollars in development aid being misappropriated by corrupt officials and siphoned into offshore accounts. The second-perhaps surprisingly to some - came from the US business community, which felt that it was at a competitive disadvantage in international business due to the fact that its foreign competitors did not face a legal burden equivalent to the US FCPA.

\section{a) Anti-Corruption and the NGO Community}

In the 1990s, individuals and organizations involved in international development began to identify and publicize the harmful effects of bribery and corruption. The most prominent NGO to engage on the issue of corruption was TI, which was founded in 1993 as a coalition of civil society and business that aimed to create a global anti-corruption movement. Industry-specific organizations also began to take action against corruption. For example, in 1995, the International Federation of Consulting Engineers began to include anti-corruption language in its model contracts, and in 1996 both the International Chamber of Commerce (ICC) and the American Bar Association (ABA) published recommendations encouraging their members to support anti-corruption activity. ${ }^{16}$

Around this same time, international development organizations and think tanks, such as the United Kingdom's Overseas Development Institute (ODI), observed greater attention to and discussion of the possibility of tying aid funding to political reform in developing countries, known as "political conditionality." The ODI noted that among other things, "the current donor interest in questions of good governance and democracy [and...] the motivation for political and institutional reform stems from a desire to improve aid effectiveness, by preventing waste and corruption and strengthening the overall policy environment."17

International organizations and international financial institutions also played a key role in providing a platform to identify the problem corruption posed to the effective use of

\footnotetext{
${ }^{16}$ Carolyn Hotchkiss, "The Sleeping Dog Stirs: New Signs of Life in Efforts to End Corruption in International Business" (1998) 17 Journal of Public Policy \& Marketing 108 at 112.

${ }^{17}$ Overseas Development Institute, Aid and Political Reform, Briefing Paper (January 1992) at 2.
} 
development aid. For example, at its 1992 High Level Meeting, the OECD Development Assistance Committee (DAC) made up of the representatives of the major foreign aid donor countries, addressed what Helmut Führer, ${ }^{18}$ called "one of the last taboo subjects," namely corruption. ${ }^{19}$ The DAC highlighted the detrimental impacts of corruption on development, observing that "corruption can result in the misuse of aid as well as domestic resources and can damage the reputation of aid efforts in donor countries" ${ }^{20}$ In 1996, the DAC formally recommended that Members introduce anti-corruption provisions for procurement that is funded by bilateral aid, in keeping with the rationale that corruption wastes the scarce resources available for development. ${ }^{21}$ The DAC Recommendation was one of the precursors to the 1997 OECD Revised Recommendation ${ }^{22}$ and subsequent OECD Convention. ${ }^{23}$

The anti-corruption campaigners of the 1990s felt that there was little prospect of disciplining governments for condoning corruption by their own officials. However, they believed that corruption could be curbed by imposing harsh penalties on the bribe payers (hence "supply side"). This belief was the motivation behind the OECD's anti-corruption work in the 1990s.

\section{b) Anti-Corruption and the US Business Community}

By the early 1990s, the US business community had become an important proponent of international anti-corruption efforts. Since 1977, US domiciled companies had been subject to domestic federal anti-corruption legislation in the form of the FCPA. While competitors from other countries were free to bribe with impunity, US companies had the burden of complying with the FCPA, which prohibited making payments to foreign government officials in order to obtain or retain business.

Soon after the US enacted the FCPA, the American business community argued that the Act disadvantaged American companies relative to foreign competitors. ${ }^{24}$ Within the first few years of the FCPA's operation, the US Government Accountability Office (GAO) conducted a survey of a sample of the largest US firms and found that $60 \%$ of respondents felt that, all other conditions being equal, American companies could not compete internationally against foreign competitors able to pay bribes. Over $50 \%$ of respondents believed that an international antibribery treaty would strengthen the US's competitive position. ${ }^{25}$ The GAO accordingly argued that Congress should urge the President to actively pursue an international agreement. ${ }^{26}$

Throughout the 1980s and 1990s, the US business community and a variety of US government actors advocated for an international treaty to address the problem of corruption and ameliorate

\footnotetext{
${ }^{18}$ Director of the OECD Development Cooperation Directorate from 1975 to 1993.

${ }^{19}$ OECD, Helmut Führer, The Story of Official Development Assistance: A History of the Development Assistance Committee and the

Development Co-operation Directorate in Dates, Names and Figures (Paris: OECD, 1993) at 60 [Führer, Story of Official Development Assistance].

${ }^{20}$ Führer, Story of Official Development Assistance at 61.

${ }^{21}$ Recommendation on Anti-Corruption Proposals for Aid-Funded Procurement, 13 May 1996 (OECD, Development Assistance Committee).

${ }^{22}$ Revised Recommendation of the Council on Combating Bribery in International Business Transactions, 23 May 1997, 36 ILM 1016 (OECD) [1997 Revised Recommendation].

${ }_{23}^{23}$ OECD, Council, OECD Actions to Fight Corruption (Note by Secretary-General), (25 May 1997) [OECD, Council, OECD Actions].

${ }^{24}$ Donald L Scantlebury, Division Director and Chief Accountant of GAO Accounting and Financial Management Division, "The Impact of the Foreign Corrupt Practices Act on U.S. Business" (Statement delivered before the Senate Committee on Banking, Housing, and Urban Affairs of the 97th Cong, 20 May 1981) at 14 [Scantlebury Statement]. Also see US, Business Accounting and Foreign Trade Simplification Act: Joint Hearing before the Senate Committee on Banking, Housing, and Urban Affairs, 98th Cong (1983) at 68, 78 [Joint Hearing].

${ }^{25}$ Scantlebury Statement at 14 .

${ }^{26}$ Scantlebury Statement at 14 .
} 
the disadvantages created by the FCPA. Industry organizations such as the US Chamber of Commerce strongly supported FCPA reform efforts to mitigate the unintended detrimental impacts of the FCPA on business. Proposed bills, such as the 1983 Business Accounting and Foreign Trade Simplification Act, not only included clarifications of US domestic legislation, but also called on the President to pursue negotiations towards an international agreement on illicit payments and report progress to Congress. ${ }^{27}$ However, it was not until the Omnibus Trade and Competitiveness Act of 1988 that the FCPA was successfully amended. Among other things, the 1988 Act required the President to negotiate an agreement with the OECD to internationalize the FCPA's anti-bribery provisions. $^{28}$

The concern that the FCPA disadvantaged the US against its economic competitors appears to explain why decision-makers chose to act specifically at the OECD. An international agreement amongst this organization's members - most of the world's largest economies accountable for the overwhelming majority of exports and foreign direct investment—would bind the US business community's major competitors, thereby leveling the economic playing field for American companies. $^{29}$

\section{c) Anti-Corruption at the OECD}

Following these developments at home, in 1989, US officials at the OECD began to advocate for other OECD Members to criminalize the bribery of foreign officials in commercial transactions. $^{30}$ This is not to say that bribery was previously absent from the policy work of the OECD; for example, the 1976 OECD Guidelines for Multinational Enterprises ${ }^{31}$ included a specific anti-bribery provision. ${ }^{32}$ However, guidelines for the conduct of multinational enterprises would far from satisfy the ambitions of the US business community that OECD countries introduce FCPA-like legislation domestically to criminalize the offer or payment of bribes to foreign officials.

As with previous efforts to develop an international agreement on illicit payments, the US efforts met opposition. Prominent OECD members such as Germany, France, Japan, and Spain, initially opposed its initiative. ${ }^{33}$ Specifically, France and Germany objected to the extraterritorial effect of the proposed bribery offence. Germany also raised concerns regarding the difficulty of detecting and proving the existence of bribery. ${ }^{34}$ However, by 1994, their opposition abated, and the

\footnotetext{
${ }^{27}$ US, Bill S 414, Business Accounting and Foreign Trade Simplification Act, 98th Cong, 1983.

${ }^{28}$ Ellen Gutterman, "Easier Done than Said: Transnational Bribery, Norm Resonance, and the Origins of the US Foreign Corrupt Practices Act" (2013) Foreign Policy Analysis 1 at 9.

${ }^{29}$ William J Clinton, "Statement by the President" (Statement delivered at the signing of the amendments to the Omnibus Trade and Competitiveness Act of 1988, 10 November 1998). US, "Proposed Legislative History" of the International Anti-Bribery and Fair Competition Act of 1998, Pub L 105-366 (1998) at 1, online: DOJ <http://www.justice.gov/criminal/fraud/fcpa/docs/leghistory.pdf> .

${ }^{30}$ Mark Pieth, "International Cooperation to Combat Corruption" in Kimberly Ann Elliot, ed, Corruption and the Global Economy (Washington, D.C.: Institute of International Economics, 1997) 119 at 122-23 [Pieth, "International Cooperation to Combat Corruption"]; US, House Commerce Committee, International Anti-Bribery and Fair Competition Act of 1998 (HR Doc No 105-802) at 13.

${ }^{31}$ OECD, Guidelines for Multinational Enterprises, 21 June 1976, 15 ILM 967 at 972 (The Guidelines were annexed to the 1976 Declaration on International Investment and Multinational Enterprises) [MNE Guidelines].

${ }_{32}^{32}$ MNE Guidelines at 14 (see especially General Policies at para 7, which states "Enterprises should [...]not render-and they should not be solicited or expected to render - any bribe or other improper benefit, direct or indirect, to any public servant or holder of public office.").

${ }^{33}$ Barbara Crutchfield George, Kathleen A Lacey \& Jutta Birmele, "The 1998 OECD Convention: An Impetus for Worldwide Changes in Attitudes toward Corruption in Business Transactions" (2000) 37 Am Bus LJ 487 at 496 [George, Lacey \& Birmele, "An Impetus for Worldwide Change"].

${ }^{34}$ George, Lacey \& Birmele, "An Impetus for Worldwide Change" at 496.
} 
OECD adopted a formal anti-corruption Recommendation. ${ }^{35}$ In addition to calling on member states to take effective measures to deter, prevent, and combat the bribery of foreign public officials, the 1994 Recommendation required the Committee on International Investment and Multinational Enterprises (CIME) to review it and its implementation within three years. ${ }^{36}$

As part of the review process, the OECD consulted with business and non-governmental organizations to obtain their input regarding the implementation of the 1994 Recommendation. $^{37}$ When developing and negotiating the draft Convention text, OECD delegations also consulted with members of the business community that had played such a significant role in putting anticorruption on the international agenda. For example, the OECD's standing advisory body, the Business and Industry Advisory Committee (BIAC), consulted closely with the OECD delegations during the negotiation of the Convention. ${ }^{38}$ The OECD has officially recognized BIAC since its founding in 1962 as the voice of the business community in OECD Member States. This is not to say, however, that members of BIAC were always unequivocal on all anticorruption issues. For example, members of BIAC were divided with respect to the appropriate scope of the Convention, e.g. whether it should apply to state-owned enterprises (through the definition of a "foreign country"), or contributions to candidates for political office and political parties (through the definition of a "public official"), among other things.

Other international business organizations were also consulted by the OECD, such as the International Chamber of Commerce (ICC), a business association whose mandate includes the promotion of an open international trade and investment system. Notably, the ICC was an early proponent of an international anti-corruption treaty. Its efforts began in 1975, when it established a committee chaired by Lord Shawcross. ${ }^{39}$ The 1977 Shawcross Report recommended that the United Nations (UN) draw up an international anti-bribery treaty and called for businesses to impose some form of self-regulation. ${ }^{40}$ However, the proposed UN Convention failed to gather enough support, and in the 1990s, the ICC shifted its attention to the OECD, perceiving it as a more effective forum within which such a treaty could be negotiated. ${ }^{41}$

\section{The OECD Anti-Bribery Convention}

\section{Developing a Binding Convention}

Although CIME was originally expected to report to the Council in May $1997,{ }^{42}$ before the Council Meeting convened, France and Germany argued that the only way to ensure fairness among all Members was to negotiate a binding convention. Moreover, they asserted that a convention was required because each country's legal systems were different. ${ }^{43}$ Both the US and

\footnotetext{
${ }^{35}$ Recommendation of the Council on Bribery in International Business Transactions, 27 May 1994, 33 ILM 1389 (OECD) [1994

Recommendation]; see Pieth, "International Cooperation to Combat Corruption" at 123.

${ }^{36} 1994$ Recommendation, art IX.

${ }^{37}$ OECD, Council, OECD Actions at 2.

${ }^{38}$ Letter from M Pieth to HK van Egmond (29 September 1997); OECD, Committee on International Investment and Multinational Enterprises,

Review of the 1994 Recommendation on Bribery in International Business Transactions, including Proposals to Facilitate the Criminalisation of Bribery of Foreign Public Officials, (26 May 1997) at 8.

${ }^{39}$ A former Attorney General of Great Britain and prosecutor at the Trial of the Major War Criminals before the International Military Tribunal, Nuremberg, 14 November 1945 - 1 October 1946.

${ }^{40}$ ICC, Commission on Ethical Practices, "Recommendations to Combat Extortion and Bribery in Business Transactions" 17 ILM 417 at 418

${ }^{41}$ OECD, No Longer Business as Usual: Fighting Bribery and Corruption (Paris: OECD Anti-Corruption Unit, 2000) at 170-71.

${ }^{42}$ Pieth, "International Cooperation to Combat Corruption" at 125.

${ }^{43}$ Paul Blustein, "Fight Looms Over Foreign Bribery; France, Germany Blocking Efforts to Outlaw Practice, U.S. Officials Say", The

Washington Post (9 May 1997).
} 
TI opposed this position, reportedly because they feared that negotiating a binding convention would take years and therefore delay international action. ${ }^{44}$

The parties reached a compromise by combining the convention proposal with a collective pledge to legislate within a specified time period. ${ }^{45}$ The 1997 Revised Recommendation therefore engaged two parallel strategies: (1) it called on Members to adopt national laws criminalizing the bribery of foreign public officials by the end of 1998; and (2) it committed the Council to open negotiations immediately to conclude an international convention to criminalize bribery by the end of 1997 in order for the convention to enter into force by the end of $1998 .{ }^{46}$

\section{2. $\quad$ Focus on the Supply-Side of Bribery Transactions}

One of the reasons that the OECD Convention is such a significant instrument in the fight against corruption is because of its focus on the supply-side of international bribery. By making the potential cost of engaging in bribery greater than its benefits, the Convention targets private companies in capital-exporting OECD countries, seeking to cut off the flow of international bribery at its source. As a result of the Convention, now all 34 OECD Member states and six additional signatories prohibit bribery of foreign officials.

The Convention binds the home countries of the vast majority of international businesses, making it an important consideration of many multinational corporations. The fact remains that even today - despite the emergence of global corporations from China, Russia, Brazil, India, Indonesia, Malaysia and many other countries - the overwhelming majority of multinational corporations are domiciled in OECD countries and therefore are subject to the foreign corruption laws introduced as a result of the OECD Convention.

\section{Content and Scope of the Convention}

The OECD Convention is short and focused, with one central obligation: Article 1 requires State parties to introduce strict measures to criminalize the bribery of foreign officials. The Convention also addresses ancillary matters such as jurisdiction, ${ }^{47}$ penalties, ${ }^{48}$ enforcement cooperation, ${ }^{49}$ and peer review. ${ }^{50}$

Despite its reach, the OECD Convention does not have the broader scope and coverage of later conventions, such as the UNCAC. Most notably, it does not address so-called "passive" bribery and the systemic or institutional challenges faced by countries where public officials solicit bribes. $^{51}$ (Of course, the distinction between so-called "active" and "passive" bribery is somewhat misleading since bribe recipients are rarely passive, and play an active role in soliciting or extorting bribes and incentivizing corrupt practices).

\footnotetext{
${ }^{44}$ Paul Blustein, "Pact to Bar Bribery is Reached; Major Nations Agree to U.S. Request", The Washington Post (24 May 1997) [Blustein, "Pact to Bar Bribery"].

${ }^{45}$ Blustein, "Pact to Bar Bribery".

${ }^{46} 1997$ Revised Recommendation, art III.

${ }^{47}$ OECD Convention, art 4.

${ }^{48}$ OECD Convention, art 3.

${ }^{49}$ OECD Convention, arts 5, 9, 10 .

${ }^{50}$ OECD Convention, art 12.

${ }^{51}$ OECD, Working Group on Bribery in International Business Transactions, Commentaries on the Convention on Combating Bribery of Foreign Public Officials in International Business Transactions, (1997) at para 1, online: OECD <http://www.oecd.org/daf/anti-

bribery/ConvCombatBribery_ENG.pdf>.
} 


\section{Implementation, Compliance and Peer Review}

Implementing obligations under the OECD Convention requires states to make legislative changes (for example, by introducing the offence of bribing a foreign public official into domestic criminal law) and follow those changes up through law enforcement activity. On both fronts, the record of compliance with the Convention by member states is mixed; however, it is steadily improving, in part as a result of the Convention's peer review process. The peer review process consists of three phases: in the first phase, peer country reviewers consider the target country's legislation. In the second phase, the reviewers examine whether the legislation that exists is effectively applied. In the third phase, the reviewers focus on enforcement efforts and any outstanding recommendations. Discussions about the scope and focus of a fourth phase of review are currently underway, ${ }^{52}$ and this further stage of review may commence in late 2015.

The intention of a peer review process is to encourage countries to "name and shame" each other, raising the bar of what constitutes adequate implementation. Peer review processes and the scrutiny of anti-corruption NGOs, which use independent metrics to monitor countries' performance, shine a spotlight on the progress or lack thereof by countries in the fight against bribery. The result has been the increasingly vigorous implementation and enforcement of foreign bribery laws - not only by the US - but also by Germany, Korea, Italy, Japan, France, Norway, Switzerland, the United Kingdom (UK), Belgium and Canada.

For example, after the OECD Working Group expressed concern about the UK's existing legislative framework, ${ }^{53}$ the UK stated its intention to reform its laws ${ }^{54}$ and ultimately introduced the Bribery Act that is today one of the more comprehensive anti-bribery laws in the world. ${ }^{55}$ Similarly, in Canada, criticism of the government's lax enforcement ${ }^{56}$ prompted both the continued acceleration of enforcement efforts and legislative amendments to implement the Working Group's key recommendations. ${ }^{57}$ Because of the supply-side focus of the Convention obligations, companies and individuals who offered or paid bribes are the focus of enforcement efforts by OECD member states. 427 foreign bribery enforcement actions have been undertaken globally since the Convention entered into force.$^{58}$ Although the peak of enforcement occurred in 2011, when 78 cases concluded, the OECD Foreign Bribery Report also discloses that foreign bribery cases are taking longer to prosecute (lengthening from an average of 2 years between the accused's last criminal act and the sanction in 1999 to an average of 7.3 years in 2013). The

\footnotetext{
52 OECD, "Public consultation on Phase 4 monitoring of the OECD Anti-Bribery Convention", online: OECD, $<$ http://www.oecd.org/corruption/2014-call-for-comment-phase-4-anti-bribery-convention.htm>.

${ }^{53}$ OECD, Working Group on Bribery in International Business Transactions, United Kingdom: Review of Implementation of the Convention and 1997 Recommendation, (1999) at 24-25, online: OECD <http://www.oecd.org/daf/anti-bribery/anti-briberyconvention/2754266.pdf>.

${ }^{54}$ OECD, Working Group on Bribery in International Business Transactions, United Kingdom: Review of Implementation of the Convention and 1997 Recommendation: Phase 1bis Report, (2002) at 1, 16-17, online: OECD <http://www.oecd.org/daf/anti-bribery/anti-

briberyconvention/2498215.pdf>.

${ }^{55}$ Bribery Act 2010 (UK), c 23.

${ }^{56}$ OECD , Working Group on Bribery in International Business Transactions, Phase 3 Report on Implementing the OECD Anti-Bribery Convention in Canada, (2011) at 6, 59-60, online: OECD <http://www.oecd.org/canada/Canadaphase3reportEN.pdf $>$ [Phase 3 Report]; OECD, News Release, "Canada's enforcement of the foreign bribery offence still lagging; must urgently boost efforts to prosecute" (28 March 2011), online: OECD

$<$ http://www.oecd.org/newsroom/canadasenforcementoftheforeignbriberyoffencestilllaggingmusturgentlyboosteffortstoprosecute.htm>.

${ }^{57}$ Foreign Affairs, Trade and Development Canada, News Release "Strengthening Canada's Fight Against Foreign Bribery" (5 February 2013), online: FATD $<$ http://www.international.gc.ca/media/aff/news-communiques/2013/02/05b.aspx?lang=eng $>$ [FATD, "Strengthening Canada's Fight"].

${ }^{58}$ OECD, OECD Foreign Bribery Report: An Analysis of the Crime of Bribery of Foreign Public Officials, (OECD Publishing, 2014) at 11, online: OECD $<$ http://dx.doi.org/10.1787/9789264226616-en> [OECD Foreign Bribery Report]. The OECD Foreign Bribery Report analyzes case information from all countries that have enacted the offence of bribery of foreign public officials in their domestic criminal law.
} 
Report speculates that a number of factors may be responsible for this trend, including the complexity of investigations and the willingness of individuals or entities accused to resist or to settle the charges against them. ${ }^{59}$

As discussed in greater detail below, in Canada, corporate fines of C $\$ 9.5$ million $^{60}$ and $\mathrm{C} \$ 10.35$ million $^{61}$ have been imposed in two cases since 2011. In 2013, the first individual was tried and convicted of conspiring to offer a bribe ${ }^{62}$ and has been sentenced to three years of imprisonment. ${ }^{63}$ In total, monetary sanctions totaling USD $\$ 5.4$ billion have been imposed in countries with a foreign bribery offence. ${ }^{64}$ These fines, together with the reputational damage of being convicted of criminal bribery, have resulted in a significant shift in corporate attitudes. $31 \%$ of cases analyzed in the OECD Foreign Bribery Report were brought to the attention of law enforcement authorities through corporations' self-reporting. ${ }^{65}$ Moreover, many multinational corporations have adopted strict anti-corruption compliance policies and other internal controls at substantial expense. Of the 137 cases brought to law enforcement through self-reporting, companies detected the bribery through internal audits $(31 \%)$ or due diligence in M\&A transactions $(28 \%)$, both of which can be complex and often resource-intensive compliance mechanisms, which indicates that companies are willing to devote time and resources to detecting and avoiding anti-corruption liability. The Convention's focus on the supply-side of bribery transactions aims to incentivize this kind of change.

\section{CANADA'S IMPLEMENTATION OF ITS INTERNATIONAL OBLIGATIONS}

\section{A. The Corruption of Foreign Public Officials Act (CFPOA)}

While all OECD countries have adopted laws to implement the OECD Convention, several have yet to enforce those laws in a serious way. For several years after its ratification of the OECD Convention, Canada was a case in point. In 1998, Canada passed the CFPOA, thus implementing its obligation under the OECD Convention to create a foreign bribery offence at domestic law. However, Canada did not commit any resources to the enforcement of the CFPOA at the time of its enactment, nor did it identify any particular agency as having primary responsibility for the investigation and prosecution of CFPOA offences.

The CFPOA is a criminal statute that prohibits the offering, promising, or giving of anything of value to a foreign public official, whether directly or indirectly, in exchange for using the foreign public official's position or influence to obtain a business advantage. In the original Act, "business" was specified to be "any business, profession, trade, calling, manufacture or undertaking of any kind carried on in Canada or elsewhere for profit". ${ }^{66}$ When the legislation

\footnotetext{
${ }^{59}$ OECD Foreign Bribery Report at 14.

${ }^{60}$ In $R$ v Niko Resources Ltd, 2011 CarswellAlta 2521 (QB) [Niko], Niko Resources pled guilty for bribing a foreign public official in Bangladesh. Through its subsidiary, Niko Bangladesh, the company provided the use of a vehicle and paid travel and accommodation expenses for the then State Minister of Energy \& Mineral Resources to attend an oil and gas industry exhibition in Calgary. The use of the vehicle was valued at approximately $\$ 191,000$ and the trip cost $\$ 5,000$. Niko was fined $\$ 9.5$ million (including a 15 percent victim surcharge).

${ }^{61} R v$ Griffiths Energy International, [2013] AJ no 412 at para 10 [Griffiths]. Griffiths Energy entered a guilty plea on one count of bribery contrary to the CFPOA and was fined C\$9 million plus a 15 percent victim surcharge for a total penalty of C $\$ 10.35$ million. Griffiths Energy admitted to having paid a C $\$ 2$ million success fee to a company controlled by the wife of the ambassador to Canada of the Republic of Chad in connection with securing an oil and gas concession in the African country.

${ }^{62} R v$ Karigar, 2013 ONSC 5199 [Karigar I].

${ }^{63} R$ v Karigar, 2014 ONSC 3093 at para 37 [Karigar II].

${ }^{64}$ OECD Foreign Bribery Report at 18.

${ }^{65}$ OECD Foreign Bribery Report at 15-16.

${ }^{66}$ CFPOA, s 2, "business" (before it was amended by An Act to amend the Corruption of Foreign Public Officials Act, SC 2013, c 26).
} 
entered into force in February $1999,{ }^{67}$ the offence was punishable by up to 5 years of imprisonment or a fine in the court's discretion.

Originally, Canada's jurisdiction over foreign bribery offences was territorial in scope: in order for Canada to have jurisdiction over an alleged offence, a court had to find that the offence had a "real and substantial connection" with Canada, pursuant to the test for jurisdiction under Canadian common law (established in $R . v$. Libman). ${ }^{68}$ In $R . v$. Karigar, the only existing jurisprudence on the application of territorial jurisdiction to the bribery of a foreign public official, the Ontario Superior Court of Justice concluded that Canada could assert territorial jurisdiction over a bribery offence where few elements of the offence as defined occurred in Canada. In rejecting the defendant's argument that the Court lacked territorial jurisdiction ${ }^{69}$ because Libman requires "'the bulk of the elements of the offence'" to have occurred in Canada, Justice Hackland held that "[t]he substantial connection test is not limited to the essential elements of the offence as submitted by the accused." ${ }^{70}$ Moreover, Justice Hackland noted that in the specific context of a bribery offence, "one cannot segregate or otherwise deal with the bribery as a separate and discrete issue thereby excluding the legitimate aspects of the transaction from consideration in applying the substantial connection test." ${ }^{71}$

\section{Elements of the Offence}

To obtain a conviction under the CFPOA for the offence of bribing of a foreign public official, the prosecution must prove both the actus reus (the prohibited act) and mens rea (a guilty mind). With respect to the proof of mens rea in this context, there is no requirement to prove a specific 'corrupt' intent. It is sufficient for the prosecution to prove that the accused, having reason to know or suspect that a third party might make or offer a bribe on its behalf, failed to make appropriate further inquiry, or to take remedial action (i.e., the doctrine of wilful blindness).The prosecution must also establish the following elements of the actus reus of the offence: a person, in order to obtain or retain business, or to retain or obtain an advantage in the course of business, directly or indirectly gives, offers or agrees to give or offer, a loan, reward, advantage or benefit of any kind, to a foreign public official or to any person for the benefit of a foreign public official, as consideration for an act or omission by the official in connection with the official's duties or functions, or to induce the official to use his or her position to influence any act or decision of the government for which the official performs duties or functions. As noted above, when first introduced, the actus reus of the offence as defined in the CFPOA required that the bribe be offered or paid to obtain an advantage in the course of business "for profit." ${ }^{72}$

The offence contemplates an exchange, or quid pro quo, between the person making the bribe and the official such that the 'benefit' is given or offered to the official in order to induce the official to use his or her official position to the business advantage of the person making the bribe. In Karigar, the Court concluded that the use of the word 'agree' in the phrase 'agrees to

\footnotetext{
${ }^{67}$ Office of the Director of Public Prosecutions, 5.8 Corruption of Foreign Public Officials, (Ottawa: Public Prosecution Service of Canada, 2014) at 2, online: PPSC <http://www.ppsc-sppc.gc.ca/eng/pub/fpsd-sfpg/fps-sfp/tpd/d-g-eng.pdf $>$ [PPSC, 5.8 Corruption of Foreign Public Officials].

${ }^{68}$ Libman at paras 74,76 .

${ }^{69}$ A pretrial ruling directed that this argument would be dealt with as a substantive defence and heard at the close of the Crown's case: 2012 ONSC 2730.

${ }^{70}$ Karigar I at para 39.

${ }^{71}$ Karigar I para 39.

${ }^{72}$ CFPOA, s 2, "business" (before it was amended by An Act to amend the Corruption of Foreign Public Officials Act, SC 2013, c 26).
} 
give or offer' imports the concept of conspiracy into the CFPOA, such that an agreement by persons to give or offer a bribe to a foreign public official is a violation of the Act, whether or not there is proof that the public official was offered or received the bribe. ${ }^{73}$ In the Karigar decision, Justice Hackland specifically observed that interpreting the legislation this way meets Canada's obligations under the OECD Convention. ${ }^{74}$

\section{Facilitation Payments}

The Canadian legislation also included an exception for "facilitation payments". The exception exempts a payment "made to expedite or secure the performance by a foreign public official of any act of a routine nature that is part of the foreign public official's duties or functions" by deeming that such payment does not amount to a "loan, reward, advantage or benefit" paid to obtain "an advantage in the course of business" such as to trigger the commission of the bribery offence. $^{75}$ Although the CFPOA does not define "acts of a routine nature", it includes an illustrative list of examples: (a) the issuance of a permit, licence or other document to qualify a person to do business; (b) the processing of official documents, such as visas or work permits; (c) the provision of services normally offered to the public, such as mail pick-up and delivery, telecommunications services and power and water supply; and (d) the provision of services normally provided as required, such as police protection, loading and unloading of cargo, the protection of perishable products or commodities from deterioration, or the scheduling of inspections related to contract performance or transit of goods. ${ }^{76}$ The CFPOA further specifies that a decision to award new business, to continue existing business or to encourage another person to make such a decision are not considered acts of a routine nature and therefore cannot fall under the exception for facilitation payments. ${ }^{77}$

\section{B. June 2013 Amendments to the CFPOA}

Although the enactment of the CFPOA was a welcome milestone in Canada's implementation of its obligations under the OECD Convention, the legislation was subject to criticism, both through the Peer Review process and in other fora. The 2004 OECD Working Group on Bribery Phase 2 Report on Canada's implementation of its obligations under the Convention identified a number of perceived legislative deficiencies, including the continued exception for facilitation payments, the "for profit" requirement in the definition of "business", and most importantly, the lack of nationality-based jurisdiction. ${ }^{78}$ In 2009 , the government had introduced Bill C-31 ${ }^{79}$ which, if passed, would have amended the CFPOA to permit nationality-based jurisdiction, however, the bill died in the committee stage when Parliament was prorogued in December 2009.

In the winter of 2011-2012, the Department of Foreign Affairs and International Trade (DFAIT, as it then was) undertook a broad consultation regarding the CFPOA. The consultation involved

\footnotetext{
${ }^{73}$ Karigar $I$ at para 28.

${ }^{74}$ Karigar $I$ at para 28.

${ }^{75}$ CFPOA, s 3(4).

${ }^{76} C F P O A, \mathrm{~s} 3(4)(\mathrm{a})-(\mathrm{d})$

${ }^{77}$ CFPOA, s 3(5).

${ }^{78}$ OECD Working Group on Bribery, Canada: Phase 2 Report on the Application of the Convention on Combating Bribery of Foreign Public Officials in International Business Transactions and the 1997 Recommendation on Combating Bribery of Foreign Public Officials in

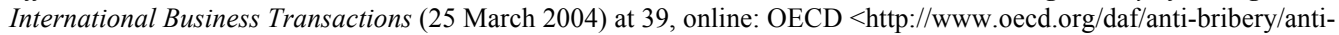
briberyconvention/31643002.pdf>.

${ }^{79}$ Bill C-31, An Act to amend the Criminal Code, the Corruption of Foreign Public Officials Act and the Identification of Criminals Act and to make a consequential amendment to another Act, 2nd Sess, 40th Parl, 2009.
} 
corporate, legal, and NGO representatives from various sectors and it resulted in the introduction of significant amendments to the CFPOA in 2013 relating to: (i) nationality jurisdiction; (ii) the clarification of the definition of "business" for the purposes of the bribery; (iii) the elimination of facilitation payments; and (iv) the establishment of a books and records offence. The amendments also increased the maximum penalty on a guilty plea or conviction for individuals (from 5 to 14 years of imprisonment) and conferred exclusive jurisdiction on the Royal Canadian Mounted Police (RCMP) for investigation and charges under the CFPOA (discussed in greater detail in section III, below).

\section{Nationality-Based Jurisdiction}

Canada's lack of nationality jurisdiction for foreign bribery offences was a significant area of concern with respect to its implementation of the OECD Convention. In its Follow-Up Report on Phase 2 in 2006, the Working Group noted that "Canada is the only Party to the Convention which has still not established nationality jurisdiction for the foreign bribery offence." ${ }^{80}$ Canada's response was that the OECD Convention did not mandate the creation of nationality-based jurisdiction; ${ }^{81}$ Article 4 of the OECD Convention requires that Parties review whether their current basis for jurisdiction is effective to fight foreign bribery. Canada took the position that the "real and substantial connection" test established in Libman has permitted Canada to extend its territorial criminal jurisdiction where circumstances warrant, and that in the one foreign bribery case concluded at the time, jurisdiction was not an issue. ${ }^{82}$ However, Canada also stated that it was monitoring this aspect of its implementation and that "if there was evidence that nationality jurisdiction is necessary to implement the Convention effectively", Canada would reconsider its implementation. ${ }^{83}$

In its Phase 2 Follow Up Report, the Working Group noted its concern was based on the "much narrower" scope for territorial jurisdiction in Canada due to the requirement that there be "substantial" links between the elements of the offence and Canada. ${ }^{84}$ Furthermore, the Working Group noted that Article 4.2 of the Convention requires countries which have established nationality jurisdiction over other offences to apply it to the offence of foreign bribery, and that as Canada has extraterritorial jurisdiction over several other offences, it should expand the scope of its jurisdiction in this context as well. ${ }^{85}$

Accordingly, the 2013 amendments established nationality-based jurisdiction for foreign bribery offences. Pursuant to the new section 5(1), Canada may take jurisdiction over offences committed outside of Canada where the person committing the offence was a Canadian citizen, permanent resident or was incorporated (or otherwise formed or organized) in Canada.

\footnotetext{
${ }^{80}$ OECD Working Group on Bribery, Canada: Phase 2 Follow-Up Report on the Implementation of the Phase 2 Recommendations on the Application of the Convention and the 1997 Recommendation on Combating Bribery of Foreign Public Officials in International Business Transactions (21 June 2006) at 4-5, online: OECD <http://www.oecd.org/daf/anti-bribery/anti-briberyconvention/36984779.pdf $>$ [OECD Phase 2 Follow-Up Report].

${ }_{82}^{81}$ Canada, "Written Follow-Up to Phase 2 Report" in OECD Phase 2 Follow-Up Report at 21 [Canada, "Written Follow-Up to Phase 2 Report"].

${ }^{82}$ Canada, "Written Follow-Up to Phase 2 Report" at 21.

${ }^{83}$ Canada, "Written Follow-Up to Phase 2 Report" at 21.

${ }^{84}$ OECD Phase 2 Follow-Up Report at 5.

${ }^{85}$ OECD Phase 2 Follow-Up Report at 5.
} 


\section{Definition of Business}

By deleting the words "for profit" in the s. 2 definition of "business," the CFPOA as amended prohibits the paying of a bribe to obtain an advantage in business, whether that business is forprofit or not-for-profit. Importantly, this expands the scope of the CFPOA to apply to the conduct of Canadian NGOs or other non-commercial entities.

Canada had originally resisted eliminating the "for profit requirement"; in its report to the OECD Working Group on Bribery, Canada indicated that it thought the CFPOA's application to forprofit activity was in keeping with reference to "Business Transactions" or "transactions commerciales" in the title of the OECD Convention. ${ }^{86}$ The Working Group disagreed, noting that the OECD Convention does not create a distinction between transactions that are for-profit and not-for-profit. ${ }^{87}$

\section{Elimination of Facilitation Payments Exception}

The treatment of facilitation payments was an issue for several Parties to the OECD Convention. Nonetheless, in its Phase 3 Report the OECD Working Group concluded that Canada was failing to implement the (post-Convention) recommendation ${ }^{88}$ that member countries periodically review their policies on and approach to facilitation payments. ${ }^{89}$ The 2009 Recommendation further recommended that Member Countries, "encourage companies to prohibit or discourage the use of small facilitation payments in internal company controls, ethics and compliance programmes or measures" ${ }^{\prime 90}$

The June 2013 amendments eliminate the CFPOA's exception for facilitation payments. Canada's response to the Phase 3 Report indicates that this amendment is a result of Canada completing a review of its policies on approaches to the issue of small facilitation payments. ${ }^{91}$ However, this change will only come into force at a future date to be determined by the federal Cabinet in order to give Canadian companies and individuals time to bring their internal controls and practices into compliance with the 'zero tolerance' approach of the revised CFPOA. ${ }^{92}$ At time of writing, no date for the entry into force of this amendment has been announced.

\section{Books and Records Offence}

The 2013 amendments created a new and separate 'books and records' offence, which criminalizes the creation or maintenance of secret, incomplete or inaccurate books and records for the purpose of engaging in or hiding the bribery of foreign public officials. Under section 4 of the CFPOA, it is now an offence to keep secret accounts, falsely record, not record or inadequately identify transactions, enter liabilities with incorrect identification of their object, use false documents, or destroy accounting books and records earlier than permitted by law for

\footnotetext{
${ }^{86}$ Canada, "Written Follow-Up to Phase 2 Report" at 20.

${ }^{87}$ OECD Phase 2 Follow-Up Report at 4.

${ }^{88}$ Recommendation of the Council for Further Combating Bribery of Foreign Public Officials in International Business Transaction, 26

November 2009 (OECD), online: OECD <http://www.oecd.org/daf/anti-bribery/44176910.pdf> [2009 Recommendation].

${ }^{89}$ Phase 3 Report at 16.

${ }^{90} 2009$ Recommendation, art VI(ii).

${ }^{91}$ Canada, "Written Follow-Up to Phase 3 Report" in OECD Follow-Up to the Phase 3 Report at 12-13 [Canada, "Written Follow-Up to Phase 3 Report"].

${ }^{92}$ Canada, "Written Follow-Up to Phase 3 Report" at 12-13.
} 
the purpose of concealing bribery of a public official. As a result, CFPOA liability can now flow from conduct relating to the financial records of a corporation made after an alleged corruption offence.

The introduction of this offence was intended to implement Article 8 of the OECD Convention, which requires that each State Party "provide effective, proportionate and dissuasive civil, administrative or criminal penalties" for omissions and falsifications of "books and records" (i.e. the books, records, accounts and financial statements of companies) that are done "for the purpose of bribing foreign public officials or of hiding such bribery". Although Canada maintained its position that the Criminal Code contains several provisions that are relevant to the Article 8 obligation, it reported that the amendments to the CFPOA supplement the Criminal Code provisions and provide law enforcement with additional tools. ${ }^{93}$

The new books and records offence is potentially the most important recent development in promoting compliance. For the first time, senior corporate officials can incur liability under the CFPOA for their conduct after a corrupt incident if they participate in or turn a blind eye to a cover-up of past misconduct.

\section{Debarment and Non-Criminal Law Mechanism}

Canada also uses alternative administrative measures to promote compliance with anti-corruption laws, including through its provision of services to Canadian companies operating abroad and public procurement policies. Since 2004, Export Development Canada (EDC) has a policy of debarring companies from EDC support until the EDC considers that the company has taken appropriate measures to deter further bribery. ${ }^{94}$ Since late 2012, the Department of Public Works and Government Services (PWGSC) (which administers procurement for the federal government) automatically disqualifies companies convicted of an offence under the CFPOA from federal government contracts. ${ }^{95}$ In Spring 2014, the Department extended this policy to disqualify companies convicted of bribery offences in foreign jurisdictions and under foreign laws. ${ }^{96}$ Also in September 2014, the federal government introduced a requirement that Canadian companies seeking the assistance of Canada's Trade Commissioners abroad must declare that they are not engaged in corruption, and specifically that neither the company nor its affiliates have been charged or convicted under Canada's anti-corruption laws. ${ }^{97}$

Subsequent to these developments, Canada's debarment regime has come under some criticism for its broad scope, perceived inflexibility, and absence of sufficient due process mechanisms, among other things. ${ }^{98}$ In its 2015 Budget, the federal government committed to introducing a

\footnotetext{
${ }^{93}$ Canada, "Written Follow-Up to Phase 3 Report" at 10.

${ }^{94}$ EDC, Anti-Corruption Policy Guidelines (January 2004), online: EDC < http://www.edc.ca/EN/About-Us/Corporate-SocialResponsibility/Documents/anti-corruption-guidelines.pdf>.

${ }^{95}$ PWGSC, PWGSC Integrity Framework (11 July 2012), online: PWGSC <http://www.tpsgc-pwgsc.gc.ca/ci-if/ci-if-eng.html>.

${ }^{96}$ PWGSC, PWGSC Integrity Framework - Backgrounder (March 2014), online: PWGSC <http://www.tpsgc-pwgsc.gc.ca/ci-if/synopsisbackgrounder-eng.html>.

${ }^{97}$ James Munson, "Ottawa makes anti-corruption waivers a condition of Trade Commissioner Service", iPolitics.ca (9 December 2014), online: iPolitics.ca <http://newcanadianmedia.ca/item/21941>.

${ }_{98}$ Barrie McKenna, "Ottawa working to modify strict anti-corruption rules" The Globe and Mail (27 January 2015), online: Globe and Mail $<$ http://www.theglobeandmail.com/report-on-business/ottawa-working-to-modify-strict-anti-corruption-rules/article22661799/>
} 
new government-wide integrity regime for its procurement and real property transactions, the details of which have yet to be announced. ${ }^{99}$

\section{CANADA'S ENFORCEMENT RECORD TO DATE}

As noted above, despite the entry into force of the CFPOA in February $1999,{ }^{100}$ there was no dedicated enforcement agency for most of the first decade of the CFPOA's existence. ${ }^{101}$ The CFPOA was originally drafted so that every police officer in the country (federal, provincial or municipal) was empowered to investigate and lay charges pursuant to its provisions. Further, an entry prosecutor (federal or provincial) could prosecute the charges it created. This approach was fundamentally ineffective. By putting everyone in charge, it effectively left no one in charge. The result was that there was little real enforcement of Canada's international corruption law until for the first decade of the CFPOA's existence, and scant attention was paid to the CFPOA by Canadian companies. Canada's lack of enforcement contrasted starkly with US FCPA enforcement through the 1990s and dramatic upswing in convictions in the 2000s, ${ }^{102}$ which culminated in the record fine paid by Siemens in 2008 (\$800 million). ${ }^{103}$

The situation changed in Canada in late 2007 and 2008. Following repeated criticism in the OECD Peer Review process and TI's annual reviews, as well as Canada's ratification of the UNCAC in October 2007, the Government established a dedicated International Anti-Corruption Unit (IACU) within the RCMP's Commercial Crime Branch. The IACU consisted of two sevenperson teams based in Ottawa (the nation's capital, and location of the centre of Canadian federal government as well as foreign embassies) and Calgary (the centre of Canada's extractive industries, and the corporate home of many companies operating in high-risk jurisdictions). Its purpose was to focus on detecting, investigating and preventing international corruption (including bribery, embezzlement and laundering of the proceeds of crime), particularly in the public sector. The two teams were coordinated and overseen by a dedicated senior RCMP officer-the Officer in Charge of Sensitive Investigation and International Corruption-a position that was established by the RCMP in $2005 .^{104}$

The result was a predictable rise in Canadian enforcement activity. The last report to Parliament on Canada's implementation of the OECD Convention in October 2014 disclosed that the RCMP had 27 anti-corruption investigations under way, ${ }^{105}$ which is fewer than the 36 active

\footnotetext{
99 Canada, "2015 Budget Plan" (21 April 2015), online: Government of Canada < http://www.budget.gc.ca/2015/docs/plan/ch5-1eng.html\#Improving_the_Integrity_of_Federal_Procurement>.

${ }^{100}$ CFPOA, s 13.

${ }^{101}$ In 2008, RCMP established the International Anti-Corruption Unit, which was dedicated to the enforcement of the CFPOA. See FATD,

"Strengthening Canada's Fight".

102 "Recent Trends and Patterns in FCPA Enforcement", (March 2006) at 2, online: Shearman \& Sterling LLP < shearman.com>.

${ }^{103}$ US Securities and Exchange Commission, Press Release, 2008-294, "SEC Charges Siemens AG for Engaging in Worldwide Bribery" (15 December 2008), online: SEC <http://www.sec.gov>. The $\$ 800$ million refers to fines paid to US authorities only. Siemens also paid $\$ 856$ million to German authorities, see Jeffrey J Meagher \& Matthew J Fader, "Siemens Pays Record $\$ 800$ Million to Settle Foreign Corrupt Practices Act Charges", (23 December 2008), online: K\&L Gates <siemens-pays-record-800-million-to-settle-foreign-corrupt-practices-act-charges-12-23$2008>$.

${ }^{104}$ TI-Canada, 2008 Progress Report Card on OECD Convention Enforcement (9 May 2008), online: TI-Canada <http://www.transparency.ca/9Files/Older/Reports-Older/CPI-OtherReports/OECD-2008-Canada.pdf>.

${ }^{105}$ Canada, Fifteenth Annual Report to Parliament: Implementation of the Convention on Combating Bribery of Foreign Public Officials in International Business Transactions, and the Enforcement of the Corruption of Foreign Public Officials Act (September 2013-August 2014) (3 October 2014), online: Foreign Affairs and International Trade, <http://www.international.gc.ca/trade-agreements-accords-commerciaux/topicsdomaines/other-autre/corr-15.aspx?lang=eng $>$.
} 
investigations at the time of the previous report to Parliament in November $2013 .{ }^{106}$ Given that the Canadian economy is one-tenth the size, these figures compare favorably with the US, where the number of active investigations is slightly over $100 .{ }^{107}$

Both federal and provincial Crown prosecutors can prosecute CFPOA offences. However, since mid-2012, the RCMP appears to have taken a policy decision to refer CFPOA matters exclusively to the Public Prosecution Service of Canada (PPSC), which represents the federal Crown in criminal prosecutions. The PPSC has designated senior counsel to coordinate CFPOA matters, and in March 2014 issued a Guideline that emphasized the importance of coordinating the prosecution of CFPOA offences at a national level. ${ }^{108}$

In addition, over the same time period, two parallel trends converged to make anti-corruption an important priority for the Canadian corporate community:

1. The fact that many of Canada's largest companies are cross-listed on US stock exchanges made them subject to the FCPA. Increasing enforcement in the US prompted greater compliance measures being implemented by US-listed Canadian companies; and

2. The potential FCPA exposure to US purchasers and lenders led to more robust due diligence in acquisitions of Canadian companies and in corporate finance involving US lenders.

The following presents an overview of key milestones in Canada's enforcement record to date.

\section{A. The Early Years: Hydro-Kleen}

As noted above, there was little active enforcement of the CFPOA during the first decade of its existence. The first case concluded in Canada involved illegal payments of C\$28,299.88 made by Hydro Kleen Systems Inc. ("Hydro Kleen") to a US immigration official, working at the Calgary International Airport. In return for these payments, the official advised Hydro Kleen's employees on how to use work visas to obtain entry into the US. Unknown to the company, the official also obstructed the entry of Hydro Kleen's competitors' personnel into the US.

The bribery scheme came to light due to complaints from a competitor whose personnel were turned back at the Calgary airport. The competitor hired a private investigator and turned over evidence to the RCMP which pursued the investigation and ultimately laid charges of bribery against both the company and an officer and director, as well as the US official. The Court fined Hydro Kleen $\$ 25,000$ pursuant to a negotiated plea ${ }^{109}$ and the charges against a director and an officer of the company were stayed. The US official was sentenced to six months imprisonment,

\footnotetext{
${ }^{106}$ Canada, Fourteenth Annual Report to Parliament: Implementation of the Convention on Combating Bribery of Foreign Public Officials in International Business Transactions, and the Enforcement of the Corruption of Foreign Public Officials Act (September 2012-August 2013) (7 November 2013), online: Foreign Affairs and International Trade, <http://www.international.gc.ca/trade-agreements-accordscommerciaux/topics-domaines/other-autre/corr-14.aspx?lang=eng $>$.

${ }^{107}$ Richard L Cassin, "The Corporate Investigations List", The FCPA Blog (8 January 2015), online: The FCPA Blog

$<$ http://www.fcpablog.com/blog/2015/1/8/these-twelve-companies-have-always-appeared-on-the-corporate.html $>$.

${ }^{108}$ PPSC, 5.8 Corruption of Foreign Public Officials at 3.

${ }^{109} R v$ Watts, [2005] AJ no 568 at paras 177, 189 [Hydro-Kleen].
} 
and was deported to the US. ${ }^{110}$ This light sentence and relatively minor fine indicated how far Canada was from the kind of active enforcement seen in other jurisdictions, including the US.

\section{B. The Second Wave: Investigations and Prosecutions in the Public Eye}

Throughout the 2000s, Canada's enforcement record remained bare, with the Hydro-Kleen prosecution being the only case prior to 2010. However, after dedicated law enforcement resources were devoted to anti-corruption in 2008, there was a noticeable upswing in enforcement activity. For example, in 2010, the RCMP laid charges against Mr. Nazir Karigar under paragraph 3(1)(b) of the CFPOA for allegedly making a payment to an Indian government official to secure a multi-million dollar procurement contract for Cryptometrics, a Canadian high-tech firm. These charges resulted in Canada's first contested trial under the CFPOA in 2013, as discussed below. In 2011, the RCMP executed a search warrant against Blackfire Exploration, a junior Calgary-based mining company, reportedly after receiving a complaint from mining watchdog NGOs. ${ }^{111}$ Also in 2011, the RCMP investigated search warrants at the offices of SNCLavalin in Oakville, Ontario related to its investigation into alleged corruption in the World Bank-funded Padma Bridge project in Bangladesh (discussed below). However, notwithstanding the importance of these developments and the benefit of the public having an opportunity to learn of them through RCMP press releases and media coverage, there was little reason for most companies to suspect how high the stakes were about to become.

In June 2011, Niko Resources Ltd., ("Niko") a Canadian public company in the oil and gas exploration sector, pleaded guilty to one count of bribery based on events that occurred in 2005 . The guilty plea was entered with an agreed statement of facts in the Alberta Court of Queen's Bench, where Niko admitted to having attempted to influence the Bangladeshi State Minister for Energy and Mineral Resources by providing a vehicle for the personal use of the thenBangladeshi Energy Minister, valued at C $\$ 190,984$ and paying the travel costs for the same Minister to attend an Energy Expo in Calgary and a subsequent personal trip to New York, valued at $C \$ 5,000$. These benefits were allegedly paid to obtain the minister's support in relation to the negotiation of a gas purchase and sale agreement with a state enterprise and mitigation of the fallout resulting from a gas blowout at one of Niko's sites in Bangladesh. ${ }^{112}$ The RCMP learned of the potential CFPOA violations through reports from DFAIT (as it then was). ${ }^{113}$

The Crown was unable to prove that any influence was obtained as a result of providing these benefits. ${ }^{114}$ Nonetheless, and notwithstanding the Crown's acknowledgement of Niko's cooperation with the RCMP investigation and guilty plea before charges were formally laid, Niko was sentenced to pay a significant fine: $\mathrm{C} \$ 8.3$ million plus a 15 percent victim surcharge, for a total penalty of C $\$ 9.5$ million. In addition, Niko was subject to a significant Probation Order, which required the company to undertake audits of its compliance with anti-corruption laws under court supervision for three years. Indeed, the substantive terms of the Niko Probation Order provide a roadmap for other companies looking to understand what robust corporate anticorruption compliance might look like.

\footnotetext{
${ }^{110} R v$ Garcia, 2002 ABPC 156 at paras 19, 32.

${ }^{111}$ Les Whittington \& Brett Popplewell, "Mining watchdogs want probe", The Toronto Star (10 March 2010), online: Toronto Star

$<$ http://www.thestar.com/news/canada/2010/03/10/mining_watchdogs_want_probe.html $>$.

${ }^{112}$ Niko at para 21 (see Agreed Statement of Facts at para 58).

${ }^{113}$ Niko at 21 (see Agreed Statement of Facts at para 45).

${ }^{114}$ Niko at 21 (see Agreed Statement of Facts at 58).
} 
Less than two years later, Canada would mark its second significant prosecution. In January 2013, Griffiths Energy International Inc. ("Griffiths") entered a guilty plea on one count of bribery contrary to the CFPOA. Griffiths admitted to having paid a C\$2 million success fee to a company controlled by the wife of the ambassador to Canada of the Republic of Chad in connection with securing an oil and gas concession in the African country. The Crown did not allege and Griffiths did not admit that any influence was actually realized as a result of these payments. $^{115}$ Indeed, when Griffiths' new board and management learned of the corrupt arrangements after a significant change in personnel at the top levels of the company, the new leadership undertook an internal investigation and shared these results with the PPSC and RCMP. $^{116}$

In total, Griffiths was fined C\$9 million plus a 15 percent victim surcharge for a total penalty of C\$10.35 million. This significant fine was levied notwithstanding the fact that the company voluntarily disclosed the matter to the Canadian and US authorities when it came to the attention of new management and cooperated fully in the RCMP investigation. In fact, the court's reasons suggest that the fine would have been considerably higher in the absence of the voluntary disclosure and Griffiths' cooperative conduct. ${ }^{117}$

Once underway, Canadian enforcement increased rapidly. As of the beginning of 2015, we have seen two corporate convictions with substantial monetary penalties (Niko and Griffiths), one individual convicted and sentenced to three years imprisonment (Karigar), as well as the use of a variety of enforcement and investigative tools, in addition to the search warrants mentioned above, including:

- The use of anti-money laundering proceedings under the Criminal Code to seize assets related to corruption;

- A grant of immunity to a corporate official in exchange for providing evidence for prosecution under the CFPOA;

- The issuance of numerous Criminal Code production orders by the courts in CFPOA cases; and

- Formal enforcement cooperation with the US Securities and Exchange Commission, US Department of Justice, UK Serious Fraud Office, Swiss Attorney General and other foreign law enforcement agencies in international corruption cases, including repeated use of Mutual Legal Assistance Treaties.

\section{Testing the CFPOA: Karigar and Pending SNC-Lavalin Cases}

Niko and Griffiths sent strong signals to the Canadian business community that CFPOA enforcement was active and serious. However, because both cases proceeded by way of what amounts to a negotiated settlement, no legal issues came before the courts to test the limits and contours of the legislation. When the first contested cases began to work their way through the

\footnotetext{
${ }^{115}$ Griffiths at para 7 (see the Agreed Statement of Facts at para 50, online: CBA

$<$ http://www.cba.org/ABC/ladefense/Pdf/Griffiths_Amended_Statement_of_Facts.pdf $>$ ).

${ }^{116}$ Griffiths at para 7 (see the Agreed Statement of Facts at paras 41-43).

${ }^{117}$ Griffiths at para 7 (see the Agreed Statement of Facts at paras 52-56).
} 
courts in 2013 and 2014, Canadian judges started to have the opportunity to clarify significant principles relevant to anti-corruption law in Canada.

\section{R. v. Karigar, 2013 ONSC 5199 (Liability) and 2014 ONSC 3093 (Sentencing)}

In June 2013, Nazir Karigar, a Canadian citizen, was found guilty of bribery under the CFPOA for an agreement to pay bribes to certain officials of Air India and the Indian Minister of Civil Aviation with regard to the procurement of an airport security system. Mr. Karigar had acted as an agent for Cryptometrics Canada, a Canadian technology company. In contesting the case against him, Mr. Karigar argued that (i) the Crown had not adduced sufficient evidence to establish the actus reus of the offence because the Crown failed to present any evidence regarding the actual payment of sums to foreign public officials, and (ii) that Canada can only assert territorial jurisdiction over the matter if there is a real and substantial connection between the essential elements of the offence and Canada.

With respect to the first issue, Justice Hackland of the Ontario Superior Court of Justice concluded that the use of the word 'agree' in the phrase 'agrees to give or offer' in s. 3(1) imports the concept of conspiracy into the CFPOA, such that an agreement by persons to give or offer a bribe to a foreign public official is a violation of the Act, whether or not there is proof that the public official was offered or received the bribe. ${ }^{118}$

With respect to the second issue, Justice Hackland concluded that the "real and substantial connection" test does not require that all of the essential elements of the offence have a substantial connection to Canada. Instead, Justice Hackland analyzed the tainted transaction as a whole, noting that it included a Canadian company and an agent (Mr. Karigar) who was for many years a Canadian business resident. Although the "directing minds" of the corrupt transaction were based in New York and the dealings with public officials occurred in India, ${ }^{119}$ at the relevant time, Mr. Karigar was employed by the Canadian company, and the advantage that would have been obtained by the payment of bribes was for the benefit of the Canadian company. Cryptometrics Canada would have been a party to the contemplated procurement contract, and much of the work would have been done by its employees in Ottawa. ${ }^{120}$

The Karigar interpretation is consistent with the earlier position taken by Canada with respect to its implementation of the CFPOA that the "real and substantial connection" test need not be interpreted so narrowly as to present a barrier to the effective prosecution of CFPOA offences. The finding in Karigar is important despite the introduction of nationality jurisdiction in 2013 since the "real and substantial connection" test still applies to the activities of non-Canadian companies and individuals for the purposes of the application of the CFPOA.

Following trial and the guilty verdict, in April 2014, Mr. Karigar was sentenced to three years imprisonment. ${ }^{121}$ In June 2014, the RCMP laid charges against three foreign nationals believed

\footnotetext{
${ }^{118}$ Karigar $I$ at paras 28-29, 33.

${ }_{119}^{119}$ Karigar $I$ at para 38.

${ }^{120}$ Karigar I at para 40.

${ }^{121}$ Karigar II at para 37.
} 
to have assisted in the bribery scheme, and Canada-wide warrants for these individuals remain outstanding. ${ }^{122}$

\section{SNC-Lavalin: Investigations and First Charges}

Corruption investigations into the activities of the SNC-Lavalin Group Inc. ("SNC") have received a significant amount of media attention since the RCMP executed a search warrant at SNC premises in September 2011 relating to the Padma Bridge construction project in Bangladesh. In addition to the Padma Bridge project, SNC has been under investigation in relation to public contracts in Libya as well as a high profile public construction project in Canada.

In 2012, the RCMP arrested and charged two former employees; after a preliminary inquiry in April 2013, both individuals were committed to stand trial, although the details of the case are subject to a publication ban. ${ }^{123}$ The same year, the RCMP charged a former senior vice-president of SNC, and two other individuals under the CFPOA in connection with the Padma Bridge investigation. ${ }^{124}$ In April 2014, the Ontario Superior Court found that Canada lacked adjudicative jurisdiction over one of these individuals, a Bangladeshi national who was not present in Canada and who lacked any citizenship or residency ties to Canada. ${ }^{125}$ Although Canadian courts may have jurisdiction over the offence, unless and until the accused is physically present in Canada or Bangladesh offers to surrender him to Canada, Canadian courts do not have jurisdiction over his person. ${ }^{126}$ Accordingly, the prosecution against the Bangladeshi national has been stayed, while the others continue. Prosecutions and investigations also continue with respect to alleged payments to third parties relating to public contracts in Libya; although charges have been laid, none of the Libya-related matters have as yet proceeded to trial. ${ }^{127}$

\footnotetext{
${ }^{122}$ RCMP, News Release, "RCMP Charge Individuals with Foreign Corruption" (4 June 2014), online: RCMP <http://www.rcmpgrc.gc.ca/ottawa/ne-no/pr-cp/2014/0604-corruption-eng.htm>; Canada, Fifteenth Annual Report to Parliament: Implementation of the Convention on Combating Bribery of Foreign Public Officials in International Business Transactions, and the Enforcement of the Corruption of Foreign Public Officials Act (September 2013-August 2014) (3 October 2014), online: Foreign Affairs and International Trade, $<\mathrm{http}$ //www.international.gc.ca/trade-agreements-accords-commerciaux/topics-domaines/other-autre/corr-15.aspx?lang=eng >.

${ }^{123}$ Canada, Fifteenth Annual Report to Parliament: Implementation of the Convention on Combating Bribery of Foreign Public Officials in International Business Transactions, and the Enforcement of the Corruption of Foreign Public Officials Act (September 2013-August 2014) (3 October 2014), online: Foreign Affairs and International Trade, $<$ http://www.international.gc.ca/trade-agreements-accords-commerciaux/topicsdomaines/other-autre/corr-15.aspx?lang=eng>; Ross Marowits, "SNC-Lavalin faces new bribery allegations" Metro (15 May 2013), online: Metro News $<$ http://metronews.ca/news/canada/673053/snc-lavalin-faces-new-bribery-allegations/>.

${ }^{124}$ RCMP, News Release, "RCMP Charge Former SNC Lavalin Senior Executive" (18 September 2013), online: RCMP <http://www.rcmpgrc.gc.ca/ottawa/ne-no/pr-cp/2013/0918-lavalin-eng.htm>; Canada, Fifteenth Annual Report to Parliament: Implementation of the Convention on Combating Bribery of Foreign Public Officials in International Business Transactions, and the Enforcement of the Corruption of Foreign Public Officials Act (September 2013-August 2014) (3 October 2014), online: Foreign Affairs and International Trade, $<$ http://www.international.gc.ca/trade-agreements-accords-commerciaux/topics-domaines/other-autre/corr-15.aspx?lang=eng $>$.

${ }^{125}$ Chowdhury v HMQ, 2014 ONSC 2635 at paras 6, 39, 52, 57 [Chowdhury].

${ }^{126}$ Chowdhury at para 54.

${ }^{127}$ In April 2012, the RCMP executed a search warrant at SNC headquarters pursuant to a mutual legal assistance request by the Swiss authorities. The Swiss authorities had arrested a former executive vice-president of SNC for money laundering and corruption, and in August 2014 reached a plea deal which saw the executive plead guilty in October 2014 to bribery in exchange for the 29 months of incarceration he served and an order to repay millions of dollars to SNC. Two weeks later, the executive was extradited to Canada, where he is expected face prosecution of the domestic corruption charges laid against him in relation to a large public construction project in Quebec. In February 2014 , the RCMP laid charges against a former executive vice-president of construction and a former vice-president and financial controller in relation to the Libya corruption allegations. In September 2014, the RCMP laid additional charges against the former executive vice-president of construction for obstructing justice and against a Canadian lawyer for obstructing justice and extortion, alleging that the two men sought to obtain a statement from the former executive vice-president detained in Switzerland in exchange for money. RCMP, News Release, "Charges Laid in Project Assistance" (10 September 2014), online: RCMP <http://www.rcmp-grc.gc.ca/ottawa/ne-no/pr-cp/2014/0910-assistance-eng.htm>.
} 
In February 2015, the RCMP laid fraud and corruption charges against SNC, its division SNCLavalin Construction Inc. and its subsidiary SNC-Lavalin International Inc. ${ }^{128}$

\section{FUTURE DIRECTIONS AND CONCERNS}

\section{A. The Challenge for Canadian Business}

As Canadian business looks to expand in new markets in the $21^{\text {st }}$ century, it is inevitable that companies will look to emerging markets. While offering lucrative business opportunities, many developing countries suffer from weak institutions and an uncertain commitment to the rule of law. This is particularly acute in resource-rich regions where Canadian businesses have a competitive advantage (e.g. mining and energy expertise). Canadian companies are increasingly adopting more robust anti-corruption compliance policies to provide some initial protection in light of their obligations under the CFPOA and due to the scrutiny of international anticorruption enforcement agencies. However, this trend towards enhancing compliance mechanisms is still in its early stages, and companies are prone to adopting formal measures rather than establishing deeply-rooted compliance cultures.

Nonetheless, the increase in enforcement levels and awareness by businesses and their legal and financial advisors is leading to significant changes in compliance and transaction practices, including:

- More exacting corruption-related representations and warranties, conditionality, covenants and indemnities in M\&A and finance agreements;

- Increasingly detailed due diligence by buyers and lenders;

- More process-driven compliance mechanisms (reporting and approval requirements);

- Tighter internal controls as companies become more familiar with the qualitative functions of enterprise software; and

- A growing cadre of experienced Canadian specialist professionals (lawyers, accountants, compliance professionals and internal investigators).

Increasing enforcement by the RCMP prompts greater compliance efforts by Canadian companies. The need to satisfy capital markets that the company business is sustainable, and that potential foreign lenders, joint venture partners, and acquirers are not "buying" a liability when they invest in Canadian business is another driver of companies making greater investments in compliance. Canadian companies that are issuers in the US are also subject to the jurisdiction of US anti-corruption laws and potential criminal and civil enforcement actions by the US Department of Justice or Securities and Exchange Commission, respectively. Resource transparency initiatives, such as those undertaken by the $\mathrm{US}^{129}$ and $\mathrm{EU}^{130}$ and announced by

\footnotetext{
${ }^{128}$ RCMP, News Release, "RCMP charges SNC-Lavalin" (19 February 2015), online: RCMP <http://www.rcmp-grc.gc.ca/ottawa/ne-no/pr$\mathrm{cp} / 2015 / 0219$-lavalin-eng.htm>.

${ }^{129}$ Dodd-Frank Wall Street Reform and Consumer Protection Act, 15 USCS § 78m(q) (2010).
} 
Canada, ${ }^{131}$ also dovetail with the evolution of compliance culture, particularly in the resource sector. Similarly, public outrage at corruption-related scandals reported by the media also contributes to greater corporate sensitivity to potential corruption issues. However, Canadian businesses will also feel countervailing pressure as they expand in more challenging markets and compete more frequently with multinationals and SOEs from countries that do not have the same level of commitment to anti-corruption enforcement. Thus, the same frustrations that prompted the US business community to advocate for an international anti-corruption agreement can be expected similarly to motivate peers in other countries to seek to level the playing field globally with respect to the supply-side of bribery transactions.

\section{B. Limitations of the OECD Convention Approach and Future Directions}

As the above analysis indicates, since 2008, Canada's enforcement of the CFPOA has taken on significant momentum in addressing the supply-side of bribery transactions involving Canadian companies. However, the OECD Convention and the laws inspired by it are not a complete solution to the issue of bribery and corruption in international business. In the following section, we summarize some of the limitations of the OECD Convention's approach and possible future directions.

Firstly, the predominate focus on "supply-side" corruption is a significant limitation to the effectiveness of the OECD Convention. Prominent signatories did not view the OECD Convention as a final solution to bribery and corruption in international business. ${ }^{132}$ Indeed, following the adoption of the OECD Convention, the US pursued "demand-side" initiatives, including the encouragement of global norms and regional and bilateral efforts. ${ }^{133}$ Members of the business community believed that the OECD Convention should have extended to international bribery in the private sector and the bribery of foreign officials for purposes other than to obtain or retain business. ${ }^{134}$ Moreover, the composition of the international business community has significantly changed. When the Convention came into force in 1999, there were few multinational corporations from outside the OECD countries. Today, leading multinationals from China, Russia, India, Brazil, Malaysia, Indonesia and many other non-OECD countries compete vigorously in international business.

The OECD Convention's scope is problematic. While non-OECD countries are beginning to adopt foreign bribery laws, the record to date is still weak and enforcement is virtually nonexistent. As a result, one of the motivations for the adoption of the OECD Convention - to level the playing field between international companies - is under increasing pressure.

In addition, the OECD Convention fails to resolve the practical realities faced by the international business community. No matter how sophisticated the compliance systems implemented, business is not conducted in situations of perfect control. When confronted with

\footnotetext{
${ }^{130}$ EC, European Parliament and Council Directive 2013/34/EU of 26 June 2013 on the annual financial statements, consolidated financial statements and related reports of certain types of undertakings, amending Directive 2006/43/EC of the European Parliament and of the Council and repealing Council Directives 78/660/EEC and 83/349/EEC, [2013] OJ, L182/19 at 44.

${ }^{131}$ Prospectors \& Developers Association of Canada, Press Release, "PDAC Applauds the Federal Government's Support for Revenue Transparency" (12 June 2013), online: PDAC <http://www.pdac.ca/multimedia/press-releases/publications---press-releases/2013/06/12/june-12$2013>$.

${ }^{132}$ United States Department of State, Battling International Bribery at vi-vii.

${ }^{133}$ United States Department of State, Battling International Bribery at vii.

${ }^{134}$ OECD, Committee on International Investment and Multinational Enterprises, Review of the 1994 Recommendation at 8.
} 
bribe solicitation or extortion by a corrupt official, business executives are faced with a sharp dilemma: resist and jeopardize the company's business objectives or succumb and jeopardize the company's legal situation (as well as the executive's own legal exposure). Even if the company has a robust compliance culture, resisting corrupt practices inevitably results in a significant diversion of employee time and corporate resources. Instead of doing business, employees find themselves spending time reporting to lawyers and compliance officers, filling out due diligence forms, and assisting internal investigations. In addition to the effort needed to maintain robust compliance, so long as the temptation to succumb to a bribe solicitation in order to gain a business advantage exists, determined individuals may succeed in circumventing internal controls, leading to both potential liability and further investigative and compliance costs. Fundamentally, companies face a continuing challenge of allocating scarce resources among competing priorities, and have to weigh the cost, benefits and risks they face when determining how robust they can afford their anti-corruption efforts to be.

This reality supports the belief that there is a need to make greater efforts to address "demandside" corruption. A striking imbalance exists between the effort and resources devoted to addressing supply-side and demand-side corruption. While OECD Members have committed substantial resources to investigate and prosecute international bribery, they have devoted little to developing mechanisms to assist their companies when confronted with bribe solicitation or extortion. An admonition to private enterprises to "just say no" and pointing to the applicable laws is of little practical assistance. Some bodies, such as the United Nations Office on Drugs and Crime (UNDOC) have issued practical guides which address demand-side issues, but these remain dependent of the willingness of governments to address corruption internally. ${ }^{135}$

If the international community could reach a sustained consensus to address the demand-side of bribery transactions as they have with supply-side corruption, international mechanisms could be developed to assist companies trying to behave ethically, furthering the gains made in the development of corporate compliance efforts to date. What is needed is a menu of tools to allow companies confronted by corruption to obtain the assistance of the international community to resist without exposing their entire investment in the host country to ransom. This challenge goes beyond the scope of criminal law. The following are suggestions for future examination and development:

- International organizations such as the UN and its various agencies could explore the establishment of a high-level contact point for the reporting of bribe solicitation and the development of a registry of official corruption. Similar to the "name and shame" logic of peer review systems used to assess legislative compliance with and enforcement of international anti-corruption conventions, such a registry would create a internationallyaccessible record of historic country risk based on bribe solicitations themselves.

- Countries could explore the development of collective action through a joint diplomatic mechanism that could address persistent bribe solicitations or endemic corruption. For example, there have been discussions within the OECD, TI, the B20 and in other fora regarding the establishment of a high-level reporting mechanism to allow companies faced with bribe solicitation or extortion to bring the matter to the attention of high levels

\footnotetext{
135 See e.g., UNDOC, Technical Guide to the United Nations Convention Against Corruption (2009), online: UNDOC < http://www.unodc.org/documents/corruption/Technical_Guide_UNCAC.pdf>.
} 
of government through an independent channel. This proposal could also be extended and internationalized by enabling a multilateral forum to respond to such allegations. The implementation of such a mechanism would require a serious commitment on the part of the countries involved at the very highest levels to combat corruption, as well as measures to protect companies invoking the procedure from retaliation.

- The OECD and other conventions encourage states to adopt nationality-based jurisdiction over their companies' international conduct. A measure of symmetry would be provided by a limited jurisdiction on the bribe payer's country over the bribe solicitor, i.e. the corrupt foreign official. Although criminal jurisdiction is likely not feasible, including as a result of international comity and sovereign equality, there may be other forms of enforcement or jurisdiction that strike an appropriate balance. For example, civil jurisdiction backed by banking and travel sanctions could be equally effective if enforced multilaterally.

- Introduce official corruption as a cause of action in international investment treaties. This will protect businesses that are committed to ethical conduct by affording them a mechanism to seek redress for the loss of business or other harm that may result from resisting a bribe solicitation.

These measures may not be easy to develop or implement, and may not garner an international consensus any time soon. However, there is ample scope for international efforts against "demand-side" corruption just as there was against "supply-side" corruption. Moreover, unless the demand-side is addressed, the achievements on the supply-side may well risk being eroded over time to everyone's detriment.

The focus on the supply-side corruption has led to important results evidenced by the substantial resources committed to corporate compliance, training, internal controls and internal investigations. Robust compliance policies and internal controls impose costs that go beyond the direct costs of their implementation. However, they also impose transaction costs indirectly through the diversion of management's attention from business decision-making, and the delays caused by the adherence to formal compliance obligations, such as due diligence and reporting, even where the risks are less significant or non-existent. At the same time, even the most robust compliance regimes can be circumvented if the incentives are high enough, and circumventers devote sufficient effort. As in all areas of public policy, it is important to make sure that limited resources are allocated efficiently. The effort devoted to fighting supply-side corruption will ultimately result in a misallocation of scarce resources, and the reversal of its results, unless it is matched by an equivalent effort on the demand-side. 